Page 536-553. ISBN: 978-602-6 988-75-1

Web Jurnal Online: jurnal.unmuhjember.ac.id

By: Faozen

Work Stress: Antesedent Variables And Its Impact On Employee Motivation And Performance (Case Study At The University of Muhammadiyah Jember)

\title{
WORK STRESS: ANTESEDENT VARIABLES AND ITS IMPACT ON EMPLOYEE MOTIVATION AND PERFORMANCE (Case Study at the University of Muhammadiyah Jember)
}

\author{
Faozen \\ D3 Hospitality FISIP UM-Jember \\ J1. Karimata No.49 Jember Postal Code 69121 \\ Email: faozen@unmuhjember.ac.id
}

\begin{abstract}
Abstrak
The impact of work stress is decreased work motivation and employee performance. Work motivation is needed by individual employees as an encouragement to create work passion. Employee performance arises as an effective response to work tasks performed by employees. High workload will cause stress on employees. Job stress is caused by work conflict, workload, work environment and leadership influence. This research is intended to test the antenene variables of work stress on work motivation and employee performance as dependent variables. The results of this study indicate that the first hypothesis is that the work conflict variable has a positive and significant effect on work stress. The second hypothesis shows that the workload variable has a positive and significant effect on work stress. Whereas in the third hypothesis the results of the study indicate that the work environment variables have a significant and significant effect on work stress. The fourth hypothesis shows that the leadership variable has no significant effect on employee work stress. While the fifth hypothesis is that the work stress variable does not significantly influence work motivation. The sixth hypothesis proves that the variable that work motivation has a positive and significant effect on employee performance. Hypotheses to seven proving that variable work stress effect and are not significant to Performance employees.
\end{abstract}

Keywords: Work Conflict, Workload, Work Environment, Leadership, Work Stress, Work Motivation, Employee Performance 
Proceeding ICOGISS 2019

Page 536-553. ISBN: 978-602-6 988-75-1

Web Jurnal Online: jurnal.unmuhjember.ac.id

By: Faozen

Work Stress: Antesedent Variables And Its Impact On Employee Motivation And Performance (Case Study At The University of Muhammadiyah Jember)

\section{INTRODUCTION}

Manpower is one of the important factors that must be considered by companies in order to achieve its objectives. In this case, the company's ability to manage resources in a planned manner is demanded, especially human resources as the operational staff of the company to produce efficiency and effectiveness in every company activity (Ramdhani: 2011).

Employees face increasingly difficult challenges in dealing with company demands that demand high performance for the survival of the company. Organizational development is also influenced by technological changes, because in order to develop, in addition to being supported by a good management system, it is also accompanied by using more sophisticated machinery and equipment, both for operational and administrative purposes of the company. In this case, inevitably the company must be able to provide and create skilled, capable, skilled and ready-to-use personnel in carrying out jobs that increasingly demand higher work capabilities. This role is usually manifested in the form of contribution of ability and potential to the implementation of tasks related to the activities of the company concerned. In order for that role to always produce optimal results, a continuous training program is needed for both newly accepted and long-time employees in the company (Yuli: 2010).

These overly severe challenges can result in frustration or stress on employees and there is a possibility of conflict that will cause tension which often manifests in aggressive attitudes and behavior, too much criticism or protest, rebellion or other negative behaviors. From the beginning until now, with the increasingly severe challenges, employees have a high workload and can cause fatigue in work, therefore the problem of stress and conflict always arises in the corporate environment (Yuli: 2010).

In the face of globalization, employment is also increasingly expected to contribute to improving the quality of human resources which are the basic capital and at the same time the key to the success of national development, which will be reflected in increased professionalism, independence, work ethic, and work productivity. To support all of that, a healthy, safe, comfortable, and workforce work environment and work environment are required to increase work productivity (Yuli: 2010). Stress and conflict experienced by employees if left unchecked without settlement will have a negative impact on the employees themselves and the company. The negative impact for employees is the decline in employee performance, such as sales targets are not achieved, employee health becomes decreased and finally there are conditions where employees cannot continue their work. While the negative impact on the company is the decline in corporate income as a result of a decrease in employee work (Yuli: 2010) ..

These negative impacts that affect the employees themselves and the company can be minimized, so work motivation is needed, namely as something that creates enthusiasm or work motivation that will determine the size of the achievement or performance that he achieved. In the previous research, there was still a controversy about the results which showed that the relationship between the research variables as proposed in this study turned out to have a positive effect and there was a negative effect as done by Romli (2010) from his research stating that the work stress variable had a positive 
Page 536-553. ISBN: 978-602-6 988-75-1

Web Jurnal Online: jurnal.unmuhjember.ac.id By: Faozen

Work Stress: Antesedent Variables And Its Impact On Employee Motivation And Performance (Case Study At The University of Muhammadiyah Jember)

effect and significant on work motivation is different from that done by Adraeni (2003) from her research stating that work stress variables do not significantly influence work motivation. In addition, leadership on work stress is what research conducted by Hmadani (2012) of her research states that leadership variables nigative and significant effect on work stress with a reversed body research conducted by Leonita (2013) from his research states that leadership variables are nigative and not significant effect on work stress. Research conducted by Angraini (2004) states that work conflict variables have no significant effect on work stress .

\section{FRAMEWORK}

This research was conducted with a framework of thought as shown in Figure 1

canture 1 Conceptual Framework

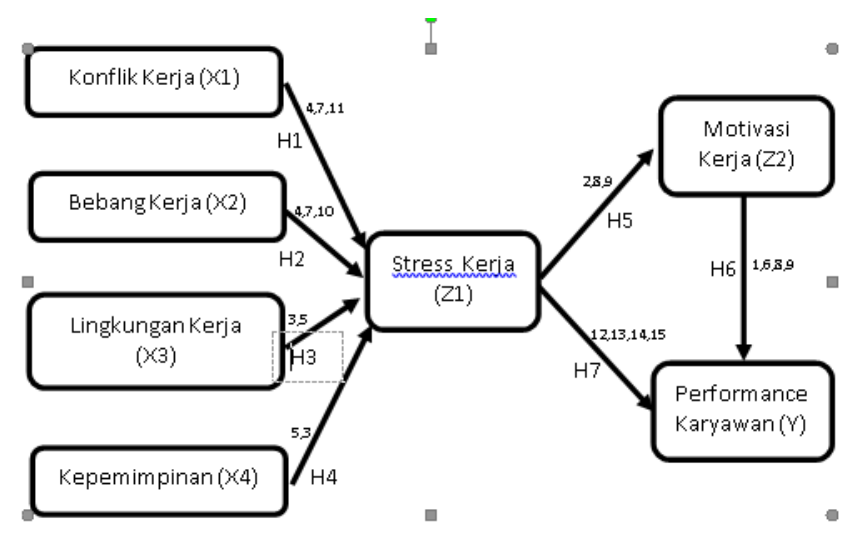

Source: Developed for this research

Information:

1. Veithzal Rivai and Dato 'AM Basri: 2005,

2. Spector (2003),

3. Dwiyanti: 2001,

4. Davis and Newstrom : 2000,

5. Stephen P. Robbins : 2004 ,

6. Cary Cooper and Alison Straw: 1995 ,

7. Munandar: 2005

8. Ni Nyoman Novitasari Andraeni (2005)

9. Asep Lili Muchamad Romli (2012)

10. Ratna Restu Noviandari (2009)

11. Azazah Indriyani, SE (2009)

12. Erika Vika (2012)

13. S. Motowidlo, J. Packard, and M. Manning (1968)

14. Raeda Fawzi AbuAlRub (2004)

15. Arbabisarjou, Ajdari Zaman, Omeidi khaled, Jalalinejad Razieh (2013) 
Page 536-553. ISBN: 978-602-6 988-75-1

Web Jurnal Online: jurnal.unmuhjember.ac.id

By: Faozen

Work Stress: Antesedent Variables And Its Impact On Employee Motivation And Performance (Case Study At The University of Muhammadiyah Jember)

\section{Hypothesis}

Based on the results of previous studies and the framework of thought, then set several research hypotheses are: $\mathrm{H} 1$ : Conflict work a positive effect on job stress, H 2 : Workload is a positive effect on job stress , $\mathrm{H} 3$ : The working environment affects nigatif against work stress , H 4 : Leadership has a positive effect on work stress , H 5 : Work stress has a positive effect on work motivation, H 6 : Work motivation has a positive effect on employee performance, H7:Job stress has a negative effect on employee performance .

\section{RESEARCH METHODS}

\section{Research stage}

This activity phase begins with the preparation of the survey, namely the research instrument test. Then after obtaining a valid and reliable instrument with a normal distribution, the surveillance team went down to explore the primary and secondary data information of course after obtaining permission from the authorities. The questionnaire that has been filled with recorded data in the field is then edited, coded and tabulated and then analyzed using the SPSS processing software application for windows. Then the next step is the preparation of a draft progress report and final report based on the results of data analysis.

\section{Population and Research Samples}

Poulasi in this research is a college employee (UM Jember). This research uses Non Probability Sampling with saturated sampling (census ) techniques . saturation sampling or the definition of saturated sampling is a sampling technique when all members of the population are used as samples.

\section{Operational Definition of Work Conflict (X1)}

Conflict is all kinds of antagonistic or antagonistic interactions between two or more parties. Conflict organization (organizational conflict) is a discrepancy between two or more members or groups of organizations that arise due to the fact that they have to $m$ embagi resources are limited it or work activities and the fact that they have different status, goals, values or even perception.

\section{Operating Variable Workload (X2)}

Workload is the extent to which an individual employee's capacity is needed in completing the tasks assigned to him, which can be indicated from the amount of work that must be done, the time / time limit owned by the employee in completing his task, as well as the individual's subjective view of the work assigned to him.

\section{Operating Variable Work Environment (X3)}

The work environment are elements of the organization as a social system that has a strong influence on the formation of individual behavior in organizations and influences the organizational achievements of Veithzal Rivai (2004). 
Page 536-553. ISBN: 978-602-6 988-75-1

Web Jurnal Online: jurnal.unmuhjember.ac.id

By: Faozen

Work Stress: Antesedent Variables And Its Impact On Employee Motivation And Performance (Case Study At The University of Muhammadiyah Jember)

\section{Operational Leadership Variable (X4)}

Leadership is a process of influencing the behavior of employees of the University of Muhammadiya Jember both individuals and groups in definite goals to achieve common goals or is an initiator, motivator, stimulator, dynamic, and innovator in an organization.

\section{Operational Variable Work Stress (Z1)}

A condition of tension that creates physical and psychological imbalances, which affect emotions, thought processes, and the conditions of employees of the University of Muhammadiya Jember or stress as emotional and psychological reactions that occur in situations where individual goals are impeded and cannot overcome them so work stress arises because the environmental demands and responses of each individual in dealing with it can be different

\section{Operational Variable Work Motivation (Z2)}

Ernest L. McCormick (in Mangkunegara, 2002: 94) work motivation as a condition that influences arousing, directing and maintaining behavior related to the work environment can also be an impulse arising from someone both internal and external encouragement that is presented in intrinsic motivation or extrinsic .

\section{Employee Performance Variable Operations (Y)}

Employee performance is an achievement achieved by someone in carrying out their duties or work in accordance with the standards and criteria set for the job

\section{Data Collection Method}

This study uses a questionnaire or questionnaire method. Therefore the interview is a set of questions given to selected respondents about matters related to the research's purpose (Nazir, 2003)

\section{Data analysis method}

Data analysis method in this research uses descriptive statistical analysis, validity test, reliability test, and using path analysis that will use SPSS for Windows Ver. 22.0.

Descriptive analysis is used to obtain an in-depth and objective picture of the object of research. Descriptive analysis uses a measuring instrument, the mean. Mean analysis is used to find out the average frequency of responses from respondents to each statement on each total variable and on each dimension of the variable.

Validity test in this study was conducted to test the accuracy of questionnaire statement items in measuring research variables. The technique used is the Pearson product moment correlation. An item statement declared valid if Pearson product moment correlation produces a significance value $(\alpha)<0.05$ (Sugiyono, 2007).

The reliability test in this study was conducted to test the reliability of the questionnaire in measuring research variables by producing consistent measurements. The technique used is the Cronbach's Alpha test. Statement items in the questionnaire are stated to be reliable if the Cronbach's Al-pha value> 0.6 (Ghozali, 2012). 
Proceeding ICOGISS 2019

Page 536-553. ISBN: 978-602-6 988-75-1

Web Jurnal Online: jurnal.unmuhjember.ac.id

By: Faozen

Work Stress: Antesedent Variables And Its Impact On Employee Motivation And Performance (Case Study At The University of Muhammadiyah Jember)

The next step, path analysis, is testing the validity of the model. Whether or not an analysis is valid depends on whether or not the underlying assumptions are met. The assumptions underlying the path analysis are:

1. In the path analysis model, the influence between variables is linear and additive

2. Only a recursive model (a causal flow system in one direction) can be considered, whereas in a reciprocal causal dependent model a path analysis cannot be performed .

3. Endogenous variables are minimal in the interval measuring scale.

4. Observed variables are measured without errors (valid and reliable measurement instruments).

The analyzed model is correctly identified based theories and concepts relevant to research.

\section{DATA ANALYSIS AND DISCUSSION}

The respondents of this study were 120 Muhammadiyah Jember University employees. Characteristics of respondents are distinguished by sex, age of education, years of service and type of employee. These characteristics are obtained from the answers of respondents on the questionnaire that has been given. Characteristics of respondents by researchers made into a table to facilitate the assessment or conclusion. it is known that of the 120 respondents, as many as $68 \%$ or as many as 82 consisted of men and $32 \%$ or as many as 38 women which means that the number of male respondents was higher than female respondents. the age of Muhammadiyah Jember University employees, respondents aged between $<25$ years were $8 \%$ or as many as 9 people, aged between $26-35$ years by $43 \%$ or as many as 51 people, aged between $36-45$ years by $20 \%$ or as many as 24 people then the age between $46-55$ years by $28 \%$ or as many as 33 people and ages between $>56$ years by $3 \%$ or as many as 3 people. From the table above it can also be seen that the most Muhammadiyah Jember University employees are employees aged between 26-35 years. respondents with an elementary education are 1 person or $1 \%$, the number of respondents who have a junior high school education are 2 people or $4 \%$, the number of respondents who have a high school education are 57 people or $48 \%$ of the total number of respondents, the number of respondents who have a D3 / S1 education is as many as 54 people or $45 \%$ and the number of respondents who have a S2 education are 3 people or $3 \%$ of the total respondents. This shows that the employees of the University of Muhammadiyah Jember mostly have high school education and are followed by D3 / S1. According to Kanuk and Schiffman (2004: 380), a person's education level is an indicator of his presence in social class. The higher the level of one's education, the more likely that someone is to obtain a higher income and have a position that is valued (higher occupational status ). the number of respondents who become permanent employees is 72 people or $60 \%$, the number of respondents who become permanent employees is 48 people or $40 \%$. This shows that the employees of Muhammadiyah Jember University were mostly permanent employees. 
Proceeding ICOGISS 2019

Page 536-553. ISBN: 978-602-6 988-75-1

Web Jurnal Online: jurnal.unmuhjember.ac.id

By: Faozen

Work Stress: Antesedent Variables And Its Impact On Employee Motivation And

Performance (Case Study At The University of Muhammadiyah Jember)

Table 1: Validity and Reliability Test

\begin{tabular}{|c|c|c|c|c|c|c|}
\hline No & Item & thithog & Keterangan & Rtabel & $\begin{array}{c}\text { Cronbach } \\
\text { Alpha }\end{array}$ & Keterangan \\
\hline \multirow{9}{*}{1} & $\mathrm{X} 1.1$ & 0,254 & Valid & 0,1779 & \multirow{9}{*}{0,854} & Reliabel \\
\hline & $\mathrm{X} 1.2$ & 0,733 & Valid & 0,1779 & & Reliabel \\
\hline & $\mathrm{X} 1.3$ & 0,718 & Valid & 0,1779 & & Reliabel \\
\hline & $\mathrm{X} 1.4$ & 0,589 & Valid & 0,1779 & & Reliabel \\
\hline & $\mathrm{X} 1.5$ & 0,750 & Valid & 0,1779 & & Reliabel \\
\hline & $\mathrm{X} 1.6$ & 0,777 & Valid & 0,1779 & & Reliabel \\
\hline & $\mathrm{X} 1.7$ & 0,755 & Valid & 0,1779 & & Reliabel \\
\hline & $\mathrm{X} 1.8$ & 0,764 & Valid & 0,1779 & & Reliabel \\
\hline & $\mathrm{X} 1.9$ & 0,660 & Valid & 0,1779 & & Reliabel \\
\hline \multirow{4}{*}{2} & $\times 2.1$ & 0,539 & Valid & 0,1779 & \multirow{4}{*}{0,441} & Reliabel \\
\hline & $\mathrm{X} 2.2$ & 0,701 & Valid & 0,1779 & & Reliabel \\
\hline & $\times 2.3$ & 0,650 & Valid & 0,1779 & & Reliabel \\
\hline & $\times 2.4$ & 0,561 & Valid & 0,1779 & & Reliabel \\
\hline \multirow{9}{*}{3} & $\times 3.1$ & 0,560 & Valid & 0,1779 & \multirow{9}{*}{0,610} & Reliabel \\
\hline & $\times 3.2$ & 0,386 & Valid & 0,1779 & & Reliabel \\
\hline & $\times 3.3$ & 0,618 & Valid & 0,1779 & & Reliabel \\
\hline & $\times 3.4$ & 0,502 & Valid & 0,1779 & & Reliabel \\
\hline & $\times 3.5$ & 0,500 & Valid & 0,1779 & & Reliabel \\
\hline & $\times 3.6$ & 0,231 & Valid & 0,1779 & & Reliabel \\
\hline & $\times 3.7$ & 0,573 & Valid & 0,1779 & & Reliabel \\
\hline & $\mathrm{X} 3.8$ & 0,599 & Valid & 0,1779 & & Reliabel \\
\hline & $\times 3.9$ & 0,450 & Valid & 0,1779 & & Reliabel \\
\hline \multirow{7}{*}{4} & $\mathrm{X} 4.1$ & 0,783 & Valid & 0,1779 & \multirow{7}{*}{0,828} & Reliabel \\
\hline & $\mathrm{X} 4.2$ & 0,764 & Valid & 0,1779 & & Reliabel \\
\hline & $\times 4.3$ & 0,536 & Valid & 0,1779 & & Reliabel \\
\hline & $\mathrm{X} 4.4$ & 0,765 & Valid & 0,1779 & & Reliabel \\
\hline & $\times 4.5$ & 0,831 & Valid & 0,1779 & & Reliabel \\
\hline & $\mathrm{X} 4.6$ & 0,788 & Valid & 0,1779 & & Reliabel \\
\hline & $\mathrm{X} 4.7$ & 0,550 & Valid & 0,1779 & & Reliabel \\
\hline \multirow{9}{*}{5} & $Z 1.1$ & 0,434 & Valid & 0,1779 & \multirow{9}{*}{0,764} & Reliabel \\
\hline & $Z 1.2$ & 0,659 & Valid & 0,1779 & & Reliabel \\
\hline & 21.3 & 0,530 & Valid & 0,1779 & & Reliabel \\
\hline & 21.4 & 0,457 & Valid & 0,1779 & & Reliabel \\
\hline & 21.5 & 0,651 & Valid & 0,1779 & & Reliabel \\
\hline & $Z 1.6$ & 0,579 & Valid & 0,1779 & & Reliabel \\
\hline & 21.7 & 0,705 & Valid & 0,1779 & & Reliabel \\
\hline & 21.8 & 0,614 & Valid & 0,1779 & & Reliabed \\
\hline & 21.9 & 0,648 & Valid & 0,1779 & & Reliabel \\
\hline \multirow{5}{*}{6} & Y1.1 & 0,825 & Valid & 0,1779 & \multirow{5}{*}{0,803} & Reliabel \\
\hline & $Y 1.2$ & 0,818 & Valid & 0,1779 & & Reliabel \\
\hline & $Y 1.3$ & 0,779 & Valid & 0,1779 & & Reliabel \\
\hline & Y1.4 & 0,769 & Valid & 0,1779 & & Reliabel \\
\hline & Y1.5 & 0,598 & Valid & 0,1779 & & Reliabel \\
\hline \multirow{9}{*}{7} & $Y 2.1$ & 0,794 & Valid & 0,1779 & \multirow{9}{*}{0,850} & Reliabel \\
\hline & $Y 2.2$ & 0,799 & Valid & 0,1779 & & Reliabel \\
\hline & Y2.3 & 0,862 & Valid & 0,1779 & & Reliabel \\
\hline & $\mathrm{Y} 2.4$ & 0,836 & Valid & 0,1779 & & Reliabel \\
\hline & $\mathrm{Y} 2.5$ & 0,506 & Valid & 0,1779 & & Reliabel \\
\hline & $Y 2.6$ & 0,714 & Valid & 0,1779 & & Reliabel \\
\hline & Y2.7 & 0,730 & Valid & 0,1779 & & Reliabel \\
\hline & $\mathrm{Y} 2.8$ & 0,302 & Valid & 0,1779 & & Reliabel \\
\hline & $Y 2.9$ & 0,431 & Valid & 0,1779 & & Reliabel \\
\hline
\end{tabular}


Proceeding ICOGISS 2019

Page 536-553. ISBN: 978-602-6 988-75-1

Web Jurnal Online: jurnal.unmuhjember.ac.id

By: Faozen

Work Stress: Antesedent Variables And Its Impact On Employee Motivation And Performance (Case Study At The University of Muhammadiyah Jember)

Based on table 4.21 it can be seen that each indicator used has a calculated value $r$ greater than 0.1779 this means that the indicators used in this research variable are feasible or valid to be used as data collectors. The test results also showed that each variable had a Cronbach Alpha value greater than 0.1779 . So it can be concluded that all variables used in this study are reliable. By knowing the significance of each of these paths will answer whether the proposed hypothesis is accepted or rejected. Each path tested represents the hypothesis in this study. The path coefficient values can be seen in the following table:

Table 2: Coefficient Value of Direct Influence Path

\begin{tabular}{|c|c|c|c|c|c|c|c|c|}
\hline No & $\begin{array}{c}\text { Var } \\
\text { Terikat }\end{array}$ & & $\begin{array}{c}\text { Var } \\
\text { Bebas }\end{array}$ & Estimate & S.E. & C.R. & P & Label \\
\hline 1 & $\mathrm{z}$ & $<---$ & $\mathrm{x} 1$ & .299 & .074 & 3.263 & .001 & Signifikan \\
\hline 2 & $\mathrm{z}$ & $<---$ & $\mathrm{x} 2$ & .201 & .083 & 2.448 & .014 & Signifikan \\
\hline 3 & $\mathrm{z}$ & $<---$ & $\mathrm{x} 3$ & -.421 & .096 & -4.917 & $* * *$ & Signifikan \\
\hline 4 & $\mathrm{z}$ & $<---$ & $\mathrm{x} 4$ & .129 & .087 & 1.591 & .112 & Tidak Signifikan \\
\hline 5 & $\mathrm{y} 1$ & $<---$ & $\mathrm{z}$ & .064 & .100 & .696 & .487 & Tidak Signifikan \\
\hline 6 & $\mathrm{y} 2$ & $<---$ & $\mathrm{z}$ & .127 & .060 & 1.558 & .119 & Tidak Signifikan \\
\hline 7 & $\mathrm{y} 2$ & $<---$ & $\mathrm{y} 1$ & .439 & .054 & 5.402 & $* * *$ & Signifikan \\
\hline
\end{tabular}

Source : 2014 data processing results

Testing the work conflict variable (X1) on work stress obtained beta value ( $\beta$ ) of 0.299 with $\rho$-value of 0.001 . Because the value of $\rho$-value is smaller than $\alpha(0.001<0.05)$, $\mathrm{H} 0$ is rejected, thus there is a significant positive effect of work conflict (X1) on work stress $(\mathrm{Z})$.

Testing the workload variable (X2) to work stress $(Z)$ obtained a beta value $(\beta)$ of 0.201 with an $\rho$-value of 0.014 . Because the value of $\rho$-value is smaller than $\alpha(0.014$ $<0.05)$, $\mathrm{H} 0$ is rejected, thus there is a significant positive effect on workload (X2) on work stress (Z).

Testing the work environment variable (X3) on work stress $(\mathrm{Z})$ obtained a beta value $(\beta)$ of -0.421 with $\rho$-value of 0,000 . Because the value of $\rho$-value is smaller than $\alpha$ $(0,000<0.05), \mathrm{H} 0$ is rejected, thus there is a significant negative effect on the work environment (X3) on work stress (Z).

testing the leadership variable (X4) on work stress $(Z)$ obtained a beta value $(\beta)$ of 0.129 with $\rho$-value of 0.112 . Because the value of $\rho$-value is greater than $\alpha(0.112<0.05)$, $\mathrm{H} 0$ is accepted, thus there is no significant influence of leadership (X4) on work stress (Z).

Testing the work stress variable $(\mathrm{Z})$ on work motivation $(\mathrm{Y} 1)$ obtained a beta value ( $\beta)$ of 0.063 with $\rho$-value of 0.487 . Because the value of $\rho$-value is greater than $\alpha(0.487$ $<0.05), \mathrm{H} 0$ is accepted thus there is no significant effect of work stress $(\mathrm{Z})$ on work motivation (Y1).

Testing the work motivation variable (Y1) on employee performance (Y2) obtained a beta value $(\beta)$ of 0.439 with a $\rho$-value of 0,000 . Because the value of $\rho$-value is smaller 
Proceeding ICOGISS 2019

Page 536-553. ISBN: 978-602-6 988-75-1

Web Jurnal Online: jurnal.unmuhjember.ac.id

By: Faozen

Work Stress: Antesedent Variables And Its Impact On Employee Motivation And Performance (Case Study At The University of Muhammadiyah Jember)

than $\alpha(0,000<0.05), \mathrm{H} 0$ is rejected, thus there is a significant positive effect of work motivation (Y1) on employee performance (Y2).

Testing the work stress variable $(\mathrm{Z})$ on employee performance (Y2) obtained a beta value $(\beta)$ of 0.127 with $\rho$-value of 0.119 . Because the value of $\rho$-value is greater than $\alpha$ $(0.119<0.05), \mathrm{H} 0$ is accepted thus there is no significant effect of work stress $(\mathrm{Z})$ on employee performance (Y2).

This section explains the calculation of the influence of work conflict variables (X1), workload (X2), work environment (X3), leadership (X4) direct and indirect effects on work motivation (Y1) and employee performance (Y2), through intervening stress variables work $(\mathrm{Z})$, and path diagram the results of the path coefficient test are presented as follows

capture 2 : Path Analysis Results

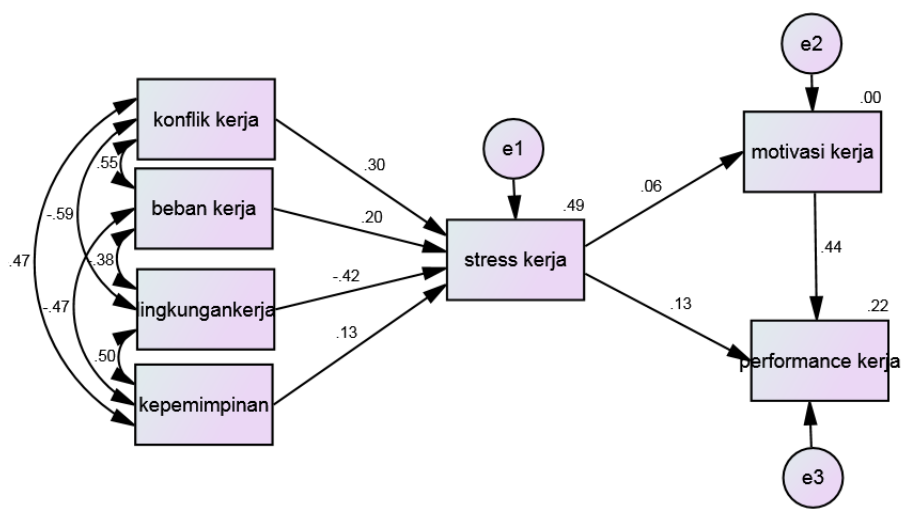

Source : 2014 data processing results

By basing the path coefficient test as in table 4.22, the model in the form of $a$ path diagram results of the path coefficient test is presented in Figure 4.2, the model can also be expressed in the form of an equation (simultaneous equation system). Path analysis in the form of an equation is presented as follows:

$\mathrm{Z}$ work stress $=0.30$ work conflict +0.20 workload $+(-0.42)$ Work environment +0.13 leadership (rounded off)

$\mathrm{Z}$ work stress $=0.299$ work conflict +0.201 workload $+(-0.421)$ Work environment + 0.129 leadership

Y1 work motivation $=0,299$ work conflict $+0,201$ workload $+(-0,421)$ Work environment +0129 leadership $+0,064$ work stress

Y2a performance $=0,299$ work conflict $+0,201$ workload $+(-0,421)$ Work Environment +0.129 leadership $+0,064$ work stress

Y2b performance $=0.299$ work conflict +0.201 workload $+(-0.421)$ Work environment +0.129 leadership +0.064 work stress +0.439 work motivation

Based on the calculation of the path coefficient, it appears that the total effect of work conflict variables (X1) on work motivation (Y1) is 0.318 , the total influence of workload variables (X2) on work motivation (Y1) is 0.214 , the total influence of work 
Proceeding ICOGISS 2019

Page 536-553. ISBN: 978-602-6 988-75-1

Web Jurnal Online: jurnal.unmuhjember.ac.id By: Faozen

Work Stress: Antesedent Variables And Its Impact On Employee Motivation And Performance (Case Study At The University of Muhammadiyah Jember)

environment variables ( $\mathrm{X} 3$ ) on work motivation $(\mathrm{Y} 1)$ is -0.444 , the total influence of leadership variable (X4) on work motivation (Y1) is 0.137 .

Based on the calculation of the path coefficient, it appears that the total effect of work conflict variables (X1) on employee performance (Y2) is 0.345 , the total influence of workload variables (X2) on employee performance (Y2) is 0.232 , the total influence of work environment variables ( $\mathrm{X} 3$ ) on employee performance (Y2) is $-0,486$, the total influence of leadership variable (X4) on employee performance (Y2) is 0,149 . the total effect of work stress variables $(\mathrm{Z})$ on employee performance $(\mathrm{Y} 2)$ is 0.028

\begin{tabular}{|l|l|l|l|l|}
\hline $\begin{array}{c}\text { Table 4.24 } \\
\text { Determination coefficient x4, x2, } \\
\text { x3, x1 to Z } \\
\text { Summary Model }\end{array}$ & & & & \\
\hline Model & R & $\begin{array}{c}\mathrm{R} \\
\text { Square }\end{array}$ & $\begin{array}{c}\text { Adjusted R } \\
\text { Square }\end{array}$ & $\begin{array}{c}\text { Std. Error of the } \\
\text { Estimate }\end{array}$ \\
\hline & & & & \\
\hline 1 & $.699^{\text {a }}$ & .488 & .470 & \\
\hline $\begin{array}{l}\text { a. Predictors: (Constant) } \mathrm{x} 4, \mathrm{x} 2, \mathrm{x} 3, \\
\mathrm{x} \text { 1 }\end{array}$ & & & & \\
\hline b. Dependent Variable: $\mathrm{Z}$ & & & & \\
\hline Source: Appendix & & & & \\
\hline
\end{tabular}

Effect of $\epsilon 1$ (variables other than $\mathrm{x} 4, \mathrm{x} 2, \mathrm{x} 3, \mathrm{x} 1$ with respect to $\mathrm{Z}$ )

$$
\begin{aligned}
& =\sqrt{ } 1-\mathrm{R}^{2} \\
& =\sqrt{ } 1-0.470 \\
& =, 50,53 \\
& =0.728 \text { or } 72.8 \%
\end{aligned}
$$

\begin{tabular}{|c|c|c|c|c|}
\hline $\begin{array}{c}\text { Table 4.25 } \\
\text { Determination coefficient z, x4, x2, } \\
\text { x3, x1 to Y1 } \\
\text { Summary Model }\end{array}$ & & & & \\
\hline Model & $\mathrm{R}$ & $\begin{array}{c}\mathrm{R} \\
\text { Square }\end{array}$ & $\begin{array}{c}\text { Adjusted R } \\
\text { Square }\end{array}$ & $\begin{array}{c}\text { Std. Error of the } \\
\text { Estimate }\end{array}$ \\
\hline 1 & & & & .271 \\
\hline
\end{tabular}

a. Predictors: (Constant), z, x4, x2, $\mathrm{x} 3, \mathrm{x} 1$

b. Dependent Variable: Y1

Source: Appendix

Effect of $\mathrm{\epsilon} 2$ (variables other than $\mathrm{z}, \mathrm{x} 4, \mathrm{x} 2, \mathrm{x} 3, \mathrm{x} 1$ on $\mathrm{Y} 1$ )

$$
=\sqrt{ } 1-\mathrm{R}^{2}
$$


Page 536-553. ISBN: 978-602-6 988-75-1

Web Jurnal Online: jurnal.unmuhjember.ac.id By: Faozen

Work Stress: Antesedent Variables And Its Impact On Employee Motivation And Performance (Case Study At The University of Muhammadiyah Jember)

$=\sqrt{ } 1-0,271$

$=, 70,729$

$=0.854$ or $85.4 \%$

\begin{tabular}{|c|c|c|c|c|}
\hline $\begin{array}{c}\text { Table } 4.26 \\
\text { Determination coefficient } y 1, \mathrm{z}, \mathrm{x} 2, \\
\mathrm{x} 4, \mathrm{x} 1, \mathrm{x} 3 \text { on } \mathrm{Y} 2 \\
\text { Summary Model }\end{array}$ & & & & \\
\hline Model & $\mathrm{R}$ & $\begin{array}{c}\mathrm{R} \\
\text { Square }\end{array}$ & $\begin{array}{l}\text { Adjusted R } \\
\text { Square }\end{array}$ & $\begin{array}{l}\text { Std. Error of the } \\
\text { Estimate }\end{array}$ \\
\hline 1 & $.550^{\mathrm{a}}$ & .303 & .266 & .38822 \\
\hline $\begin{array}{l}\text { a. Predictors: (Constant) y1, z, x2, x4, } \\
\mathrm{x} 1, \mathrm{x} 3\end{array}$ & & & & \\
\hline b. Dependent Variable: Y2 & & & & \\
\hline Source: Appendix & & & & \\
\hline
\end{tabular}

Effect of $\epsilon 2$ (variables other than $\mathrm{y} 1, \mathrm{z}, \mathrm{x} 2, \mathrm{x} 4, \mathrm{x} 1, \mathrm{x} 3$ on $\mathrm{Y} 2$ )

$$
\begin{aligned}
& =\sqrt{ } 1-\mathrm{R}^{2} \\
& =\sqrt{ } 1-0,266 \\
& =, 70,734 \\
& =0.857 \text { or } 85.7 \%
\end{aligned}
$$

Total determination coefficient: : $R_{m}^{2}=1-P_{e 1}^{2} P_{e 2}^{2} P_{e 3}^{3}$

$$
\begin{gathered}
R_{m}^{2}=1-(0,728)^{2} \cdot(0,854)^{2} \cdot(0,857)^{2} \\
=1-(0,530.0,729.0,734)
\end{gathered}
$$

$=1-0,284$

$=0,716$

The results of the calculation of the path analysis can be seen that the coefficient of determination of R2 total obtained a value of 0,716 . This means that $71.6 \%$ of the variation in employee performance variables can be explained by variables of work conflict, workload, work environment, leadership, work stress, work motivation, while the remaining $28.4 \%$ is explained by other variables and errors not explained in this study. 
Proceeding ICOGISS 2019

Page 536-553. ISBN: 978-602-6 988-75-1

Web Jurnal Online: jurnal.unmuhjember.ac.id

By: Faozen

Work Stress: Antesedent Variables And Its Impact On Employee Motivation And Performance (Case Study At The University of Muhammadiyah Jember)

\section{CONCLUSION}

The results of the analysis and discussion of Job Stress: Antecedent Variables and Their Impacts on Employee Motivation and Performance at the University of Muhammadiyah Jember based on the results of the distribution of questionnaires to 120 employees obtained conclusions are descriptive and verification as follows:

- The level of work conflict which includes truancy of employees, the formation of gangs (groups - groups), work coordination, job assignments ( job description ), work authorization, organizational goals, work perceptions, permotivasia strategies for Muhammadiya University Jember employees, average score included in the low category (not good) with an average variable of 22.4917. The problem of understanding the organization's goals compared to the other nine indicators is the highest (not so good). This is made possible by improper motivational strategies, differences in work performance and work coordination in organizations that are not given sufficient attention to cause the level of work conflict is still high at $60.8 \%$, work conflicts that occur at the employee level at the University of Muhammadiya Jember.

- Workloads which include the imposition of a task, the level of work difficulty, the adequacy of working time and the number of petrified coworkers on the employees of Muhammadiya Jember University, the average score is included in the low (not good) category with an average variable of 9.5667 . The problem with making a task worse than the other four indicators is the highest (not so good). This is possible for tasks outside office hours in the organization that need to be considered by the leadership as well as the level of difficulty of work which causes the level of workload is still high at $59.8 \%$, the workload that occurs at the employee level at the University of Muhammadiya Jember.

- The work environment which includes lighting, air temperature, noise, cleanliness, space, job security, employee relations, work atmosphere, work facilities at Muhammadiya Jember University employees, the average score is included in the high category. The problem of air circulation compared to the nine other indicators is the highest (best) with an average variable of 30.3083. This is possible for lighting, cleanliness, safety, working atmosphere, facilities and employee relations which are still high in the work environment at $67.4 \%$, the work environment that occurs at the employee level at the University of Muhammadiya Jember

- Leadership which includes mutual trust, appreciation, attention, welfare, work satisfaction, recognition of the employees of Muhammadiya Jember University, the average score is included in the high category. The problem is the extent to which the leader respects the ideas of employees and the opinions of their subordinates compared to the seven other indicators that are the highest (the best) with an average variable of 27.22250. This is possible for a climate of mutual trust, satisfaction factors, recognition of subordinate status, comfort of work which is still high at $77.8 \%$, leadership at Muhammadiya University in Jember

- Job stress which includes swelling of tasks, less clever supervisors, limited work time, lack of trust, career development opportunities, interpersonal relations among 
Proceeding ICOGISS 2019

Page 536-553. ISBN: 978-602-6 988-75-1

Web Jurnal Online: jurnal.unmuhjember.ac.id

By: Faozen

Work Stress: Antesedent Variables And Its Impact On Employee Motivation And Performance (Case Study At The University of Muhammadiyah Jember)

Muhammadiya Jember University employees, the average score is in the low (not good) category with an average variable of 24,5417 . The problem is getting work that often changes in the workplace compared to the nine other indicators that are the highest (not so good). This is possible for too many assignments, lack of responsibility, role ambiguity, change in type of work, career opportunities, interpersonal relationships that become work stress is still high at $59.9 \%$, work stress that occurs in employees at Muhammadiya University Jember

- Work motivation which includes the need for appreciation, socialization, affiliation, appreciation, self-actualization of Muhammadiya University Jember employees, the average score is included in the high (good) category with an average variable of 18.44417. The problem is the need to be affiliated compared to the other five indicators which are the highest (the best). It is possible that self-actualization needs, appreciation, appreciation, affiliation which is still high work motivation that is equal to $73.8 \%$, work motivation that occurs in employees at the University of Muhammadiya Jember

- Employee performance which includes work quality, work quantity, knowledge and skills, communication, creativity, level of absenteeism, effectiveness, work commitment to employees of Muhammadiya Jember University, the average score is included in the high category (very good) with an average variable of 36,2917 . The problem is work commitment compared to the nine other indicators that are the highest (the best). This is possible commitment, effectiveness, creativity, communication, quality, quantity which is still a high performance employee performance that is equal to $80.6 \%$, employee performance that occurs in employees at the University of Muhammadiyah Jember

1. Work conflict has a positive and significant influence on employee work stress at Muhammadiya University in Jember, with a magnitude of influence of 0.299 , which means that $29.90 \%$ of the employee's work stress variable is determined by work conflict, while the remaining $70.10 \%$ is determined by other factors not examined in model. These results indicate that work conflict as an internal factor has an important role in the work stress fluctuation of Muhammadiya University Jember employees. This shows that employee work conflict has a role in the occurrence of work stress, where the higher the level of work conflict, the higher the level of employee work stress.

2. Workload has a positive and significant effect on employee work stress at Muhammadiya University in Jember, with a magnitude of influence of 0.201 , which means that $20.10 \%$ of the work stress variable is determined by workload, while the remaining $79.90 \%$ is determined by other factors not examined in model. These results indicate that workload as an important role in the work stress fluctuations of Muhammadiya University Jember employees. This shows that the workload of employees has a role in the occurrence of work stress, where the higher the level of workload, the higher the level of employee work stress. 
Proceeding ICOGISS 2019

Page 536-553. ISBN: 978-602-6 988-75-1

Web Jurnal Online: jurnal.unmuhjember.ac.id

By: Faozen

Work Stress: Antesedent Variables And Its Impact On Employee Motivation And Performance (Case Study At The University of Muhammadiyah Jember)

3. The work environment has a significant and negative influence on the work stress of Muhammadiya University Jember employees, with a magnitude of -0.421 , which means that $42.10 \%$ of the employee's work stress variables are determined by the work environment, while the remaining $57.90 \%$ is determined by other factors not examined in the model. These results indicate that the work environment as having an important role in creating work stress of Muhammadiya University Jember employees. This shows that the work environment of employees has a role in the occurrence of work stress, according to Robbin's theory in Dwiyanti (2001) the work environment is a factor causing job stress, while according to Erika Vika (2012) examines the Analysis of the Effects of Conflict Management and Work Stress Against Performance Employees show that the work environment has a negative effect on work stress

4. Leadership has an influence but is not significant to the work stress of Muhammadiya Jember University employees, with a large influence of 0.129 which means that $12.90 \%$ of the leadership variables contribute to work stress, while the remaining $87.10 \%$ is determined by other factors not examined in the model. These results indicate that leadership as having an important role but not directly in creating work stress employees of the University of Muhammadiya Jember. This shows that leadership has an indirect role in job stress, according to Sibarani, Magdalena Linda Leonita, shows that leadership influences and is not significant to employee work stress

5. Job stress has an influence but is not significant on the work motivation of employees of Muhammadiya University in Jember, with a large influence of 0.064 , which means that $6.40 \%$ of work stress variables have a role in work motivation, while the remaining $93.60 \%$ is determined by other factors not examined in the model. . These results indicate that work stress has a role but is very small and does not directly create employee work motivation at the University of Muhammadiya Jember. This shows that work stress has an indirect role to work motivation, according to previous research conducted by Ni Nyoman Novitasari Andraeni which states that work stress does not significantly influence work motivation

6. Work motivation has a positive and significant impact to the $\mathrm{p}$ erformance employees of the University of Muhammadiyah Jember, with great influence, which means 0,439 $43.90 \%$ variable $\mathrm{p}$ erformance of employees is determined by the motivation to work, while the remaining $56.10 \%$ is determined by other factors not examined in model. These results indicate that motivation as having an important role in improving p erformance employees of the University of Muhammadiyah Jember. This shows that employee motivation has a role in improving $\mathrm{p}$ erformance employees, of which more tingging employee motivation levels, the higher the level of $\mathrm{p}$ erformance employees

7. Job stress has significant influence but not to the performance employees of the University of Muhammadiyah Jember, with great influence, which means $12.70 \%$ 0.127 job stress variables have a role at $\mathrm{p}$ erformance employees, while the remaining $87.30 \%$ is determined by other factors not examined in model. These results indicate that job stress has a role, but small and not directly in creating p erformance employees of the University of Muhammadiyah Jember 
Proceeding ICOGISS 2019

Page 536-553. ISBN: 978-602-6 988-75-1

Web Jurnal Online: jurnal.unmuhjember.ac.id

By: Faozen

Work Stress: Antesedent Variables And Its Impact On Employee Motivation And Performance (Case Study At The University of Muhammadiyah Jember)

\section{REFERENCE}

A.A Anwar Prabu Mankunegara, 2005, Evaluasi Kinerja SDM, Bandung, Aditama.

-------, 2008. Manajemen Sumber Daya Manusia, Bandung, PT. Remaja Rosdakarya.

-------, 2002, Manajemen Sumber Daya Manusia Perusahaan, Bandung, PT. Remaja Rosdakarya.

AbuAlRub, Raeda Fawzi, 2004, Job Stress, Job Performance, and Social Support Among Hospital Nurses, Journal Of Nursing Scholarship, Vol.36, No.1, Hal.73-78

Achnad S Ruky, 2002, Sukses Sebagai Manager Profesional Tampa Gelar MM atau $M B A$, Jakarta, PT SUN.

Abdul Hamid Mursi, 1997, Manajemen Sumber Daya Manusia Yang Produktif Pendekatan Al-Qura'an dan Sains, Jakarta, Gema Insani Press.

Aditya Ramdhani 2011, Pelaksanaan Program Pelatihan dan Kompetensi Pengaruhnya Terhadap Kinerja Karyawan di PT Otto Phrmaceutical Industries, Tesis Magister Manajemen ,Universitas Bina Nusantara

Asep Lili Muchamad Romli, 2010, Pengaruh stres kerja terhadap motivasi kerja dan dampaknya terhadap kinerja karyawan di PT.BPR syariah PNM Al Ma'soem, Tesis Magister Manajemen, Universitas Komputer

Augusty Ferdinand, 2006, Metode Penelitian Menejemen, Semarang, BP UNDIP

Andreas Agung Kristanto, 2009, Causing Factors Of Work Stress Among ICU's Nurses In Type C Hospital At Semarang City, Tesis Magister Manajemen, Universitas Diponegoro

Arbabisarjou, Ajdari Zaman, Omeidi khaled, Jalalinejad Razieh, 2013, The relationship between Job stress and performance among the hospitals nurses, World of Sciences Journal, No.2, Hal. 181-188

Azazah Indriyani, 2009, Pengaruh Konflik Peran Ganda Dan Stress Kerja Terhadap Kinerjaperawat Wanita Rumah Sakit (Studi Pada Rumah Sakit Roemani Muhammadiyah Semarang), Tesis Magister Manajemen ,Universitas Diponegoro

Beehr, T.A. and Newman, J.E. 1978. Work stress, Employee Health, and Organizational Effectiveness: A facet analysis, model, and literature review. Personnel Psychology, Personnel Psychology, Vol.31, No. 4, Hal. 665-699

Childre, D, 2001, Mengatasi Stres Dalam Satu Menit : Freeze-Frame, Jakarta, Prestasi Pustaka

Cahayani, Ati, 2005, Strategi dan Kebijakan Manajemen Sumber Daya Manusia, PT Indeks, Jakarta.

Davis, Keith \& Newstrom, 2000, Perilaku Dalam Organisasi, Edisi ketujuh, Jakarta , Erlangga

Dharma, Agus, 2003. Manajemen Supervisi: Petunjuk Praktis Bagi Para Supervisor, Jakarta, Raja Grafindo Persada,

Dessler, Gary, 2000, Manajemen Sumber Daya Manusia, Edisi Terjemahan,, Jakarta, PT. Prenhallindo,.

Djokosantoso Moeljono, 2005, Cultured! Budaya Organisasi Dalam Tantangan, Jakarta, PT Elex Media Komputindo 
Proceeding ICOGISS 2019

Page 536-553. ISBN: 978-602-6 988-75-1

Web Jurnal Online: jurnal.unmuhjember.ac.id By: Faozen

Work Stress: Antesedent Variables And Its Impact On Employee Motivation And Performance (Case Study At The University of Muhammadiyah Jember)

Eddy Yunus dan Irsa Komar, 2009, Work Stress and Compensation Be Able to Influence

Toward Employee Performance in Gamma Rays Division of Middle Type Customs Office in Customs Tanjung Perak Surabaya, HUMANIORA Vol. 8, No. 1

Erika Vika, 2012, Analisis Pengaruh Manajemen Konflik Dan Stres Kerja Terhadap Kinerja Karyawan Pada Pt. General Adjuster Indonesia, Tesis Magister Manajemen, Universitas Binanusantara

Endar Sugiarto, 1998, Psikologi Pelayanan dalam Industri Jasa, Jakarta, Gramedia Pustaka Utama

Emill, K, 2008, Manajemen Sumber Daya Manusia. Jakarta,Gramedia.

Fuad Masíud. 2004. Survai Diagnosis Organisasional Konsep \& Aplikasi. Badan Penerbit Universitas Diponegoro. Semarang.

Gibson, Ivancevich dan Donnelly, 1999, Organisasi dan Manajemen : Prilaku. Struktur, Proses, Edisi Keempat, Jakarta, Erlangga,.

Hasibuan, S.P. Melayu, 2003, MSDM, Edisi Revisi, Jakarta ,PT. Bumi Aksara,.

Heru Kurniantaotjahjono, 2003, Budaya Organisasi dan Balace Scorecard, Yogyakarta, UPFE UMY

Hani Handoko, 1992, Menejemen Personalia, Yogyakarta, BPFE.

Indriyo Gitosudarmo, dan Agus Mulyono, 1999, Prinsip Dasar Manajemen, Yogyakarta, BPFE.

Indriyo Gitosudarmo, 2001, Pengantar Bisnis, Yogyakarta, BPFE.

Kenna, Eugene Mc dan Beeck, Nic, 2000, The Managemen Sumber Daya Manusia, Yogyakarta, Andi.

Kartono, K. 1989. Psikologi Sosial untuk Manajemen Perusahaan dan Industri.Jakarta : Rajawali Press

Kouzes dan Posner. 2004. Manajemen Konflik Dalam Organisasi, Bandung, Alfabeta,

Lensufiie, Tikno, 2010. Leadership untuk Profesional dan Mahasiswa, Jakarta, Erlangga,

Lloyd L., dan Rue, Leslie W. 2007. Human resource management. (9th ed.). New York: McGraw-Hill Irwin

Munandar,A.S. 2001, Psikologi Industri Dan organisasi, Jakarta ,UI Press.

Mangkuprawira, Sjafri. 2001. Manajemen Sumber Daya Manusia Strategik, Bogor, Ghalia Indonesia

Moeljono Djokosantoso, 2003. Beyond leadership, Jakarta, PT. ELex Media,

Imam Moedjiono. 2002. Kepemimpinan \& Keorganisasian, Yogjakarta, UII Press,

Matondang, 2008. Kepemimpinan: Budaya Organisasi Dan Manajemen Strategik. Edisi Pertama, Yogyakarta, Graha Ilmu,

Nawawi Handani, 1999, Metode Penelitian Ekonomi, Jakarta, Erlangga,

Novita Sari, 2010 Pengaruh stres kerja terhadap motivasi kerja dan dampaknya terhadap kinerja karyawan di PT. H.M. Sampoerna, Tesis Magister Manajemen, Universitas Paramadina

Hasibuan, Malayu, S. P, 2002, Manajemen Sumber Daya Manusia Dasar, Jakarta, Bumi Aksara.

Hasibuan, Malayu, S. P, 2009. Manajemen Sumber Daya Manusia, Jakarta, Bumi Aksara, 
Proceeding ICOGISS 2019

Page 536-553. ISBN: 978-602-6 988-75-1

Web Jurnal Online: jurnal.unmuhjember.ac.id By: Faozen

Work Stress: Antesedent Variables And Its Impact On Employee Motivation And Performance (Case Study At The University of Muhammadiyah Jember)

Handoko,1992, Manajemen Personalia dan Sumber Daya Manusia, Edisi 2, Yogyakarta ,BPFE,

Haryanti, Faridah Aini, Puji Purwaningsih, 2013, Hubungan Antara Beban Kerja Dengan Stres Kerja Perawat Di Instalasi Gawat Darurat RSUD Kabupaten Semarang, Jurnal Managemen Keperawatan . Vol.1, No. 1, Hal. 48-56

Ivancevich Dkk, 2007, Behavior and Management, New York, Mc Graw Hill

Kartono, Kartini, 2005. Pemimpin Dan Kepemimpinan Edisi Pertama, Jakarta, Raja Grafindo Persada,

Luthan, Fred, 2006. Perilaku Organlsasi. Yokjakana, Andi.

Oei, Istijanto. 2010. Riset Sumber Daya Manusia. Jakarta ,PT Gramedia Pustaka Utama,

Spector, Paul E, 2003, Industrial and Organizational Psychology: Research and Practice, london, sage publication

Ratna Restu Noviandari, 2010, Analisis Pengaruh Stres Kerja Terhadap Kinerja Karyawan (Studi Kasus PT. Pos Indonesia (Persero) Jakarta Timur 13000, Magister Manajemen, Institut Pertanian Bandung

Rotua Siahaan, 2010, The Influence of Stress in Work Towards Employees Performance (Case Study at Departement of Plant, PT. Nippon Indosari Corpindo, Cikarang Bekas, Tesis Magister Manajemen, Institut Pertanian Bandung

Robbins, Stephen P dan Judge, Timothy A, 2004, Perilaku Organisasi : Organizational Behavior, BukuI, Edisi12, Jakarta, Salemba Empat,.

Robbins, Stephen P. 2001, Perilaku Organisasi, Buku I, Edisi 9, Jakarta, Gramedia,.

Robbins, Stephen, P dan Timothy A. Judge, 2008. Perilaku Organisasi. Edisi Kedua Belas, Jakarta, Salemba Empat,

Robbins, Stephen P, 2003. Perilaku Organisasi. Jakarta, Gramedia,

Robbins, Stephen P, 1994, Teori Organisasi; Struktur, Desain dan Aplikasi, Jakarta: Arcan

Smith,Perry M, 2003, Mengembang Tanggung Jawab Dan Mengambil Pilihan Yang Tepat, Jakarta, Mitra Utama

Schuler, Randall dan Jakson, Susan E, 1997, Managemen Sumber Daya Manusia Menghadapi Abad 21, Jakarta, Erlangga.

-----1999, Managemen Sumber Daya Manusia Menghadapi Abad 21, Jakarta, Erlangga.

Sondang Siangiang P, 2002, Manajemen Sumber Daya Manusia, Jakarta, Bumi Angkasa.

Susilo Martoyo,1992, Managemen dan Motivasi, Jakarta, PT Angkasa.

Sulle, Erni Tisnawati dan Saefullah, Kurniawan, 2005, Pengantar Manajemen, Edisi I, Cetakan I, Jakarta, Prenada Media,.

Sugiyono, 2006, Pendekatan Kuantitatif, Kualitatif, Research and development. Bandung , Alfabeta.

Sjafri Mangkuprawira .Dr.Ir, 2002, Menejemen Sumber Daya Manusia, Bogor, Ghalia Indonesia

Supardi dan Syaiful Anwar, 2002, Dasar-Dasar Perilaku Organisasi, Yogjakarta, UII Press,

Sofyandi, Herman, 2008. Manajemen Sumber Daya Manusia, Yogyakarta, Graha Ilmu, 
Proceeding ICOGISS 2019

Page 536-553. ISBN: 978-602-6 988-75-1

Web Jurnal Online: jurnal.unmuhjember.ac.id By: Faozen

Work Stress: Antesedent Variables And Its Impact On Employee Motivation And Performance (Case Study At The University of Muhammadiyah Jember)

Sieve M. Jex, 2002, Psychology a Scientist Practilioner Approach, New York. John Wiley \& Sons,lnc.

Syafrizal Situmorang dan Muslich Lutfi, 2012. Analisis Data untuk Riset Manajemen dan Bisnis, Medan, USU Press,

Motowidlo, Stephan J dan Packard, John S dan Manning, Michael R, 1986, Occupational Stress: Its Causes and Consequences for Job Performance, Journal of Applied Psychology, Vol.71, No.4, Hal 618-629

Miftah Thoha, 2009. Kepemimpinan Dalam Manajemen, Edisi Pertama, Jakarta, Rajawali Pers,

Veithzal Rivai dan Dato' Ahmad Fawzi Mohd. Basri, 2005, Performance Appraisal, Jakarta, PT Raja Grafindo Persada.

Veithzal Rivai, 2003, Kepemimpinan dan Perilaku Organisasi, Jakarta, PT. Raja Grafindo Persada.

Veithzal Rivai dan Sagala, Ella J, 2009, Manajemen Sumber Daya Manusia untuk Perusahaan dan Teori ke Praktik, Edisi Kedua, Jakarta, Raja Grafindo Persada,

Veithzal Rivai dan Deddy Mulyadi, 2003, Kepemimpinan dan Perilaku Organisasi, Jakarta, Raja Grafindo Persada,

Veithzal Rivai, 2004 Kepemimpinan dan Perilaku Organisasi, Jakarta, Raja Grafindo Persada,

Vicky; Antonius, 2012, Analisis Pengaruh Kompensasi Dan Manajemen Konflik Terhadap Retensi Karyawan Dan Dampaknya Pada Kinerja Karyawan Pt. Pacific Jaya Niaga, Tesis Magister Manajemen, Universitas Binanusantara

Winardi, 1994, Kamus Ekonomi, Bandung, ALM.

Widodo Hariyono, Dyah Suryani, Yanuk Wulandari, 2009, Hubungan Antara Beban Kerja, Stres Kerja Dan Tingkat Konflik Dengan Kelelahan Kerja Perawat Di Rumah Sakit Islam Yogyakarta Pdhi Kota Yogyakarta, Jurnal KES MAS Vol. 3, No. 3, Hal 162-232

Wiranata, Anak Agung 2011. Pengaruh Kepemimpinan terhadap Kinerja dan Stres Kerja Karyawan. Jurnal Ilmiah Teknik Sipil. Vol 15 No.2, Hal 62-72

Wirawan. 2010. Konflik dan Manajemen Konflik, Jakarta, Salemba Humanika,

Wahyudi. 2006. Manajemen Konflik dalam Organisasi, Bandung, Alfabeta,

Yuli Tania,2010, Analisis Pengaruh Stress Kerja, Konflik Kerja Dan Motivasi Kerja Terhadap Kinerja Karyawan Pada Pt. Cempaka Bersamamaju, Tesis Magister Manajemen ,Universitas Bina Nusantara 